\title{
三维分析技术揭示小鼠不同脑区小胶质细胞 具有不同的结构特征
}

\author{
成晓峰,巨富荣, 张胜祥” \\ 兰州大学生命科学学院, 兰州 730000 \\ *联系人, E-mail: sxzhang@1zu.edu.cn \\ 收稿日期: 2017-03-13; 接受日期: 2017-06-26; 网络版发表日期: 2017-08-01 \\ 国家自然科学基金(批准号: 31471045)资助
}

\begin{abstract}
摘要小胶质细胞是中枢神经系统中具有免疫功能的细胞, 其分枝状突起不断伸出或回缩监测着周围环境 的变化. 为了探究不同脑区中小胶质细胞突起结构特征的差异性, 本项研究采用小胶质细胞表达绿色荧光蛋白 的转基因小鼠(Mus musculus), 结合组织透明、激光共聚焦扫描成像和三维重建等技术, 对小鼠大脑皮层、纹状 体和海马齿状回变形层中小胶质细胞的结构进行了量化分析, 并利用小胶质细胞突起均由胞体发出并在三维 空间中具有连续性的特征分割出了具有复杂突起结构的单个完整小胶质细胞. 研究结果显示, 纹状体中小胶质 细胞的空间占有体积显著高于大脑皮层和海马齿状回变形层中小胶质细胞的空间占有体积, 而大脑皮层和海 马齿状回变形层中小胶质细胞突起的空间占有体积之间不具有显著性差异. 三维分析结果表明, 大脑皮层、纹 状体和海马齿状回变形层中小胶质细胞突起的总长度、分支总数、分支点个数、分支末端总数、最大分支级 数均具有显著性差异. 组织透明技术结合三维重建技术可在多个角度分析小胶质细胞的空间结构特征, 这为进 一步分析小胶质细胞结构和功能的关系及其在病理条件下的变化提供了一种新的手段.
\end{abstract}

关键词小胶质细胞, 组织透明, 三维重建, 小鼠

小胶质细胞是中枢神经系统中的免疫细胞 ${ }^{[1]}$. 健 康成熟大脑中的小胶质细胞处于静息态, 它通过分枝 状突起的伸长与回缩监测着大脑内环境的变化 ${ }^{[2]}$. 在 中风、阿尔兹海默病、脑外科创伤等病理条件下, 小 胶质细胞会发生突起回缩, 突起分支数减少等形态结 构的改变, 并可进一步向阿米巴状的激活态转化 ${ }^{[3-6]}$. 在相同的病理条件下, 不同脑区中小胶质细胞突起形 态结构的变化并不完全相同 ${ }^{[7 \sim 9]}$. 例如, 在中风条件下, 纹状体中的小胶质细胞突起比大脑皮层中的减少了
更多分支结构 ${ }^{[7]}$. 不同脑区中形态结构发生不同程度 变化的小胶质细胞能通过向外分泌不同水平的整合 素、白细胞分化抗原、一氧化氮合成酶等细胞因子 发挥不同的生理功能 ${ }^{[10]}$. 也有研究表明, 不同脑区中 静息态小胶质细胞的形态结构并不相同 ${ }^{[11]}$. 小胶质细 胞分枝状突起的形态结构十分复杂 ${ }^{[2]}$, 二维平面内的 测量结果不能全面地反映小胶质细胞突起的结构特 征. 为了更加全面地研究不同脑区中静息态小胶质 细胞形态结构的差异性, 有必要在三维水平上对小鼠

引用格式: 成晓峰, 巨富荣, 张胜祥. 三维分析技术揭示小鼠不同脑区小胶质细胞具有不同的结构特征. 中国科学: 生命科学, 2017, 47: 877-884 Cheng X F, Ju F R, Zhang S X. Three-dimensional analysis revealed that microglia have different structural features in different brain regions of mice (in Chinese). Sci Sin Vitae, 2017, 47: 877-884, doi: 10.1360/N052016-00343 
(Mus musculus)不同脑区中小胶质细胞的形态结构进 行多指标的量化分析.

随着转基因技术和成像技术的发展, 三维测量被 已被广泛地应用于细胞形态的观察与量化分析. 然而, 由于激光共聚焦显微镜在小鼠脑组织中的 $Z$ 轴成像深 度有限, 而小胶质细胞突起具有较大的空间占有体积, 传统手段难以在小鼠脑组织中获得完整小胶质细胞 的三维图像, 从而很难实现完整小胶质细胞突起结构 在三维水平上的量化分析. 近年来, 组织透明技术的 发展有效增加了共聚焦显微镜在组织中 $Z$ 轴方向上的 成像深度 ${ }^{[12]}$. 利用组织透明技术和共聚焦显微镜光学 切片扫描成像技术, 可以实现完整小胶质细胞的三维 分析.

本研究以小胶质细胞表达有绿色荧光蛋白(green fluorescent protein, GFP) 的转基因小鼠为研究对象, 采用PACT(passive clarity technique) 对脑片进行透明 处理 ${ }^{[12]}$. 通过激光共聚焦显微镜对透明后的脑片逐层 扫描获得了不同脑区中小胶质细胞的连续光学切片, 在对小胶质细胞三维重建后进一步量化并比较了大 脑皮层、纹状体和海马齿状回变形层中小胶细胞的 三维形态特征, 分析了不同脑区中小胶质细胞结构的 差异, 这些结果为进一步研究小胶质细胞的功能提供 了一定的参考依据.

\section{1 材料与方法}

\section{1 实验动物}

本实验采用购自美国 Jackson 实验室的 $\mathrm{CX} 3 \mathrm{CR} 1^{\mathrm{GFP} /+}$ 转基因小鼠(编号 005582), 该转基因小 鼠的小胶质细胞表达有 $\mathrm{GFP}^{[13]}$. 小鼠饲养在温度为 $22^{\circ} \mathrm{C} \pm 2^{\circ} \mathrm{C}, 12 \mathrm{~h}$ 光照 $/ 12 \mathrm{~h}$ 黑暗照明的环境中. 实验小 鼠年龄为2 3 个月. 所有实验程序均遵循相应的动物 实验管理条例, 并以尽量避免或减少实验动物遭受痛 苦为准则.

\section{2 取材、固定与切片}

腹腔注射 $5 \%$ 的氨基甲酸乙酯将实验小鼠深度麻醉 后, 依次用 $20 \mathrm{~mL}$ 磷酸盐缓冲液(phosphate buffer saline, PBS)和含有 $4 \%$ 多聚甲醛的PBS心脏灌流后取脑. 完整 的脑组织在 $4 \%$ 多聚甲醛溶液中 $4^{\circ} \mathrm{C}$ 避光过夜. 将固定
好的脑组织采用振动切片机连续冠状切片, 切片厚度 为 $300 \mu \mathrm{m}$.

\section{3 脑组织透明}

分别选取含有大脑皮层、纹状体和海马齿状回 变形层的脑片, 通过PACT进行透明处理 ${ }^{[12,14]}$. 流程如 下: 脑片在A4P0溶液(4\%丙烯酰胺, $0.25 \%$ 偶氮二异丁 味唑啉盐酸盐, 溶剂为 $1 \times \mathrm{PBS}, \mathrm{pH} 7.5 ; 4^{\circ} \mathrm{C}$ 环境中配制 与存储) 中 $4^{\circ} \mathrm{C}$ 过夜后连同 $\mathrm{A} 4 \mathrm{P} 0$ 溶液一起置于一密闭 试剂瓶中, 通过真空泵抽气 $5 \mathrm{~min}$ 后通 $10 \mathrm{~min}$ 氮气以完 全置换瓶中的氧气. 将处理好的试剂瓶在 $37^{\circ} \mathrm{C}$ 摇床上 避光孵育, 待丙烯酰胺单体完全聚合后将脑片取出, 再用 $37^{\circ} \mathrm{C}$ PBS清洗以去除附着在脑片表面的聚丙烯 酰胺, 然后用 $8 \%$ 十二烷基硫酸钠溶液 $40^{\circ} \mathrm{C}$ 摇床清洗至 脑片透明. 透明后的脑片用PBS过夜清洗以除去十二 烷基硫酸钠, 清洗完成后的脑片以 $70 \%$ 山梨醇溶液为 封片剂封片.

\section{4 激光共聚焦扫描成像}

所有脑片均采用配备有 $25 \times$ 物镜 (NA, 1.05) 的 Olympus FV1000激光共聚焦显微镜扫描成像. 激发光波长为 $488 \mathrm{~nm}, Z$ 轴步距为 $0.5 \mu \mathrm{m}, X Y$ 平 面尺寸为 1024 像素 $\times 1024$ 像素, 立体像素尺寸为 $0.248 \mu \mathrm{m} \times 0.248 \mu \mathrm{m} \times 0.5 \mu \mathrm{m}$. 在大脑皮层第2 4 层, 选取 介于Bregma点后1.3 1.8 mm, 距离矢状缝 $1.5 \sim 3.0 \mathrm{~mm}$ 所在区域内的小胶质细胞进行量化分析.

\section{5 图像处理与数据分析}

将获得的图像通过AutoQuant X3 (Media Cybernetics, 美国)软件进行三维盲反卷积处理以提高图像的信 噪比和去模糊. 采用Imaris(Bitplane, Swissland) 软件根 据小胶质细胞突起均由胞体发出并在三维空间中具有 连续性的特征对 5 只小鼠每个脑区中的 10 个完整小胶 质细胞进行了自动追踪, 并对重建后的三维模型进行 了人工核对, 以确保小胶质细胞三维重建后数据完整. 根据三维空间中小胶质细胞所有突起末端点组成的点 集创建凸包后计算凸包的体积, 并对三维重建后小胶 质细胞的突起总长度、末端点总个数、分支点总个 数、最大分级数和分支总数进行量化. 数据通过 $\bar{x} \pm \mathrm{SD}$ 表示, 组间比较采用 $t$ 检验和方差分析(ANOVA). 


\section{2 结果与分析}

\section{1 透明处理对GFP苂光信号和脑片面积的影响}

为了增加共聚焦显微镜在脑组织中 $Z$ 轴方向上的 成像深度和改善图像质量, 本研究采用PACT将小胶质 细胞特异性表达 $\mathrm{GFP}$ 的 $\mathrm{CX} 3 \mathrm{CR} 1^{\mathrm{GFP} /}$ 转基因小鼠脑组 织切片进行了透明处理. 结果发现, 在明视场下, 处于 未经透明处理厚度为 $300 \mu \mathrm{m}$ 脑片下方的字迹由于脑 片遮挡而难以分辨(图1A), 而经过透明处理后脑片下 方的字迹清晰可辨(图1B), 说明通过PACT处理后的脑 组织具有更好的透光性. 同时, 共聚焦显微镜扫描结 果显示透明后不同深度小胶质细胞的细小突起也保留 有荧光信号(图1C和D). 本课题组测量了共聚焦显微镜 在透明处理前后脑组织中 $Z$ 轴方向的成像深度, 发现 共聚焦显微镜在未经透明处理的脑组织中的可成像深 度约为 $70 \mu \mathrm{m}$, 而在透明处理后的脑组织中可以获得 $250 \mu \mathrm{m}$ 以上的成像深度(图1E), 表明透明处理能显著 增加共聚焦显微镜在脑组织中 $Z$ 轴方向上的成像深度. 为了研究PACT透明处理是否会对脑组织中的GFP苂 光信号带来影响, 本研究采用共聚焦显微镜对透明前 后的脑片进行扫描成像, 并分析了表层 $(Z$ 向深度小于 $15 \mu \mathrm{m})$ 小胶质细胞胞体的平均荧光强度, 发现相比于 正常组织中的小胶质细胞, 透明处理后其GFP荧光信 号发生了一定的衰减, 衰减幅度为 $18.2 \% \pm 4.4 \%$ (图1F). 此外, 为了量化PACT透明处理对脑片形态的影响, 分 别测量了透明前后脑片的面积. 统计结果显示, 相比 于透明前的脑片, 透明后脑片的面积显著性增大, 增 大幅度为 $24.8 \% \pm 5.9 \%$ (图 1G). 以上结果表明, PACT透 明处理能显著增加共聚焦显微镜在脑组织中 $Z$ 轴方向 的成像深度, 同时也保留了原组织中绝大部分的苂光 信号, 但会增大脑片的面积.

\section{2 大脑皮层中小胶质细胞突起的三维结构特征 及空间分布}

由于组织切片后能直接通过共聚焦显微镜获取的 图像深度有限, 以往对小胶质细胞形态差异性的研究 大多只是分析了小胶质细胞在二维平面内的结构特 征. 本研究发现, 小胶质细胞在三维空间中最大径向跨 度的平均值为 $(80.5 \pm 2.9) \mu \mathrm{m}$, 因此不经过透明处理的 传统手段难以利用共聚焦显微成像得到完整小胶质细 胞的三维图像. 为了更加全面地对大脑皮层中完整的
小胶质细胞进行三维分析, 本研究将 $\mathrm{CX} 3 \mathrm{CR} 1^{\mathrm{GFP} /}$ 转基 因小鼠的脑组织取出固定后, 用振动切片机制备成厚 度为 $300 \mu \mathrm{m}$ 的冠状脑切片, 经透明处理后用共聚焦显 微镜进行逐层扫描, 从而实现了完整小胶质细胞的图 像获取和三维重建(图2A C). 为了量化大脑皮层中小 胶质细胞突起的三维结构特征, 首先测量了大脑皮层 中小胶质细胞突起的总长度和末端总数, 结果显示其 总长度的 $\bar{x}$ 为 $(1107.3 \pm 87.7) \mu \mathrm{m}$, 最小值为 $833.4 \mu \mathrm{m}$, 最 大值为 $1580.2 \mu \mathrm{m}$; 末端总数的 $\bar{x}$ 为 $68.8 \pm 5.4$ 个, 最小值 为 51 个, 最大值为 90 个. 为了进一步量化大脑皮层中小 胶质细胞突起的分叉情况, 在本研究中将小胶质细胞 突起发生分支的每一个位点定义为分支点, 对分支点 的总数目进行了统计 (图2D), 结果显示其 $\bar{x}$ 为 $72.3 \pm 2.5$ 个. 分枝状突起的分级情况是小胶质细胞的一个重要 形态学指标, 为了对这一指标进行量化, 本研究将与胞 体直接相连的初始突起定义为一级突起, 在分支点处 分开的两个突起的级数通过比较这两个突起的直径来 决定, 其中直径较大分支的级数与分叉前的突起保持 一致, 直径较小分支的级数较分叉前突起的级数加一 (图2E), 然后分析了突起具有的最大级数. 结果发现, 大脑皮层中小胶质细胞突起最大级数的 $\bar{x}$ 为 $6.4 \pm 0.2$ 级.

为了量化大脑皮层中静息态小胶质细胞突起所 占的空间大小, 本研究以凸包为模型测量了小胶质细 胞的占有空间体积. 凸包是一个点集中所有元素组成 的凸组合的边界之和, 基于三维空间中小胶质细胞突 起所有末端点创建的凸包可作为小胶质细胞突起的 占有空间(图2F). 通过测量发现大脑皮层中小胶质细 胞突起所占空间体积的平均值为(111.5 \pm 9.7$) \times 10^{3} \mu \mathrm{m}^{3}$. 通过组间方差分析(双侧)检验这些指标之间的相关性, 结果显示突起的总长度和分支数具有显著的正相关 关系 $\left(r^{2}=0.99\right)$, 突起的末端点数和分支点数存在显著 的正相关关系 $\left(r^{2}=0.97\right)$.

\section{3 大脑皮层、纹状体和海马齿状回变形层中的 小胶质细胞具有不同的结构特征}

以往的研究结果表明, 不同脑区中小胶质细胞的 形态结构具有一定的差异性, 为了从三维水平上更加 全面地量化这种差异性, 选取了大脑皮层、纹状体和 海马齿状回变形层中完整的小胶质细胞进行三维重 建和比对分析(图3A C). 结果显示, 大脑皮层、海马 齿状回和纹状体中小胶质细胞空间占有体积分别为 

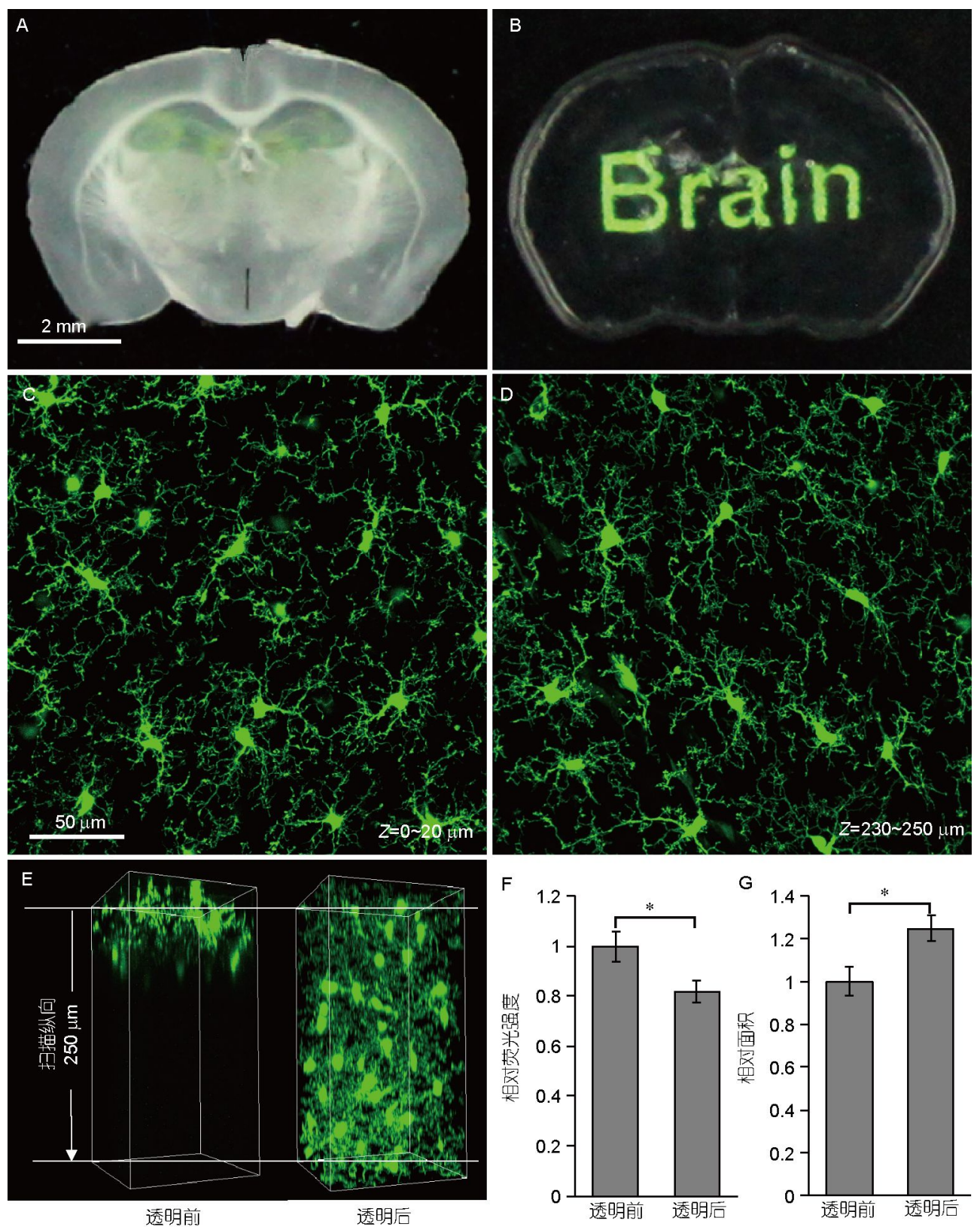

图 1 透明处理对成像深度和GFP荧光信号产生影响(网络版彩图)

A: PACT 处理前脑片下方的字迹由于脑片遮挡而难以辨认; B: PACT处理后脑片下方的字迹清晰可辨; C和D分别为PACT处理后脑片中 $Z$ 向 0 20和230 250 $\mu \mathrm{m}$ 处小胶质细胞在 $X Y$ 平面内的最大光密度投影, 图像显示透明后小胶质细胞的细小突起清晰可见; $\mathrm{E}:$ 激光共聚焦显微镜 在透明前脑片中的可成像深度约为 $70 \mu \mathrm{m}$, 在透明后脑片中的成像深度大于 $250 \mu \mathrm{m} ; \mathrm{F}$ : 透明处理后脑片中的 GFP苂光信号发生了衰减; G: 透 明后脑片的面积较透明前显著增大. $n=3$, 双尾 $t$ 检验, $*: P<0.05$

$(111.5 \pm 9.7) \times 10^{3} \mu \mathrm{m}^{3}, \quad(167.8 \pm 5.4) \times 10^{3} \mu \mathrm{m}^{3}$ 和 $(94.4 \pm$ $14.3) \times 10^{3} \mu \mathrm{m}^{3}$. 相比于大脑皮层和海马齿状回变形层, 纹状体中的单个小胶质细胞具有最大的空间占有体 积, 同时纹状体中小胶质细胞突起的总长度、分支最 大级数、分支总数、分支点个数和末端总数也显著
高于大脑皮层和海马齿状回变形层(图3D I). 这些数 据表明, 纹状体中的小胶质细胞有更复杂的分支结构, 可以监测到更大的空间范围. 三维分析结果表明, 虽 然大脑皮层和海马齿状回变形层中小胶质细胞的空 间占有体积没有明显的差异(图3I), 但是大脑皮层中 

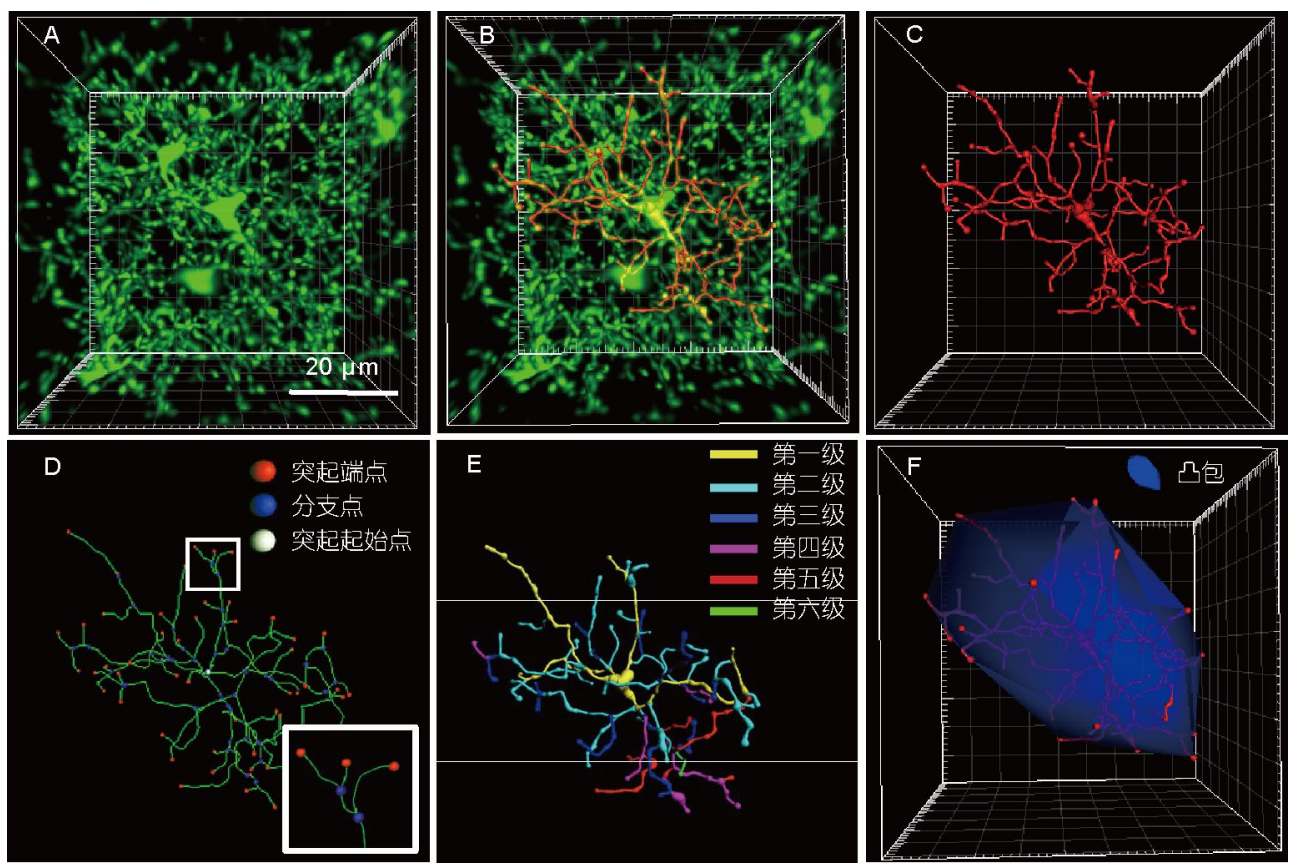

图 2 小胶质细胞突起结构和凸包的三维重建

$\mathrm{A}$ : 大脑皮层中小胶质细胞的三维视图; B: 大脑皮层中单个小胶质细胞的分割与三维重建; C: 单个小胶质细胞的三维模型; D: 根据小胶 质细胞模型定义小胶质细胞突起的末端点(红色小球)和分支点(蓝色小球); $\mathrm{E}$ : 不同颜色标示小胶质细胞突起分支所在的级数; $\mathrm{F}$ : 基 于小胶质细胞所有突起末端点组成的点集创建的凸包(蓝色)

小胶质细胞突起的总长度、分支总数、分支点个数 和末端总数都明显高于海马齿状回变形层. 该结果表 明, 大脑皮层和海马齿状回变形层中的小胶质细胞在 拥有同样的空间占有体积的情况下, 大脑皮层中的小 胶质细胞具有更加复杂的分支结构.

\section{3 讨论}

随着激光共聚焦显微镜的发展与应用, 单细胞水 平的三维重建和三维量化已被广泛地应用于细胞形态 的观察与分析 ${ }^{[15,16]}$. 然而, 受限于激光共聚焦显微镜在 不透明组织中有限的 $Z$ 轴成像深度, 传统手段难以获 得小鼠大脑中完整小胶质细胞的三维图像. PACT透明 处理可以在保留细胞原有结构的同时增加共聚焦显微 镜在组织中的成像深度 ${ }^{[12]}$, 采用 PACT对 $\mathrm{CX} 3 \mathrm{CR} 1^{\mathrm{GFP} /+}$ 小鼠脑组织处理后发现共聚焦显微成像技术在透明 的脑组织中可获取更深层次的GFP苂光信号. 通过测 量发现透明处理后GFP荧光信号会发生衰减, 但同时 脑片的体积也会有所增大, 这些数据表明透明处理造 成的总苂光信号的损耗幅度比预期的小. 因此, PACT 结合共聚焦扫描成像技术适用于小鼠大脑中完整小
胶质细胞的三维成像.

本研究在脑组织三维数据中分割出了具有复杂 突起结构的单个完整小胶质细胞, 并利用三维凸包模 型量化了单个小胶质细胞在三维空间中的占有体积, 这在以往的二维分析水平上都不能实现. 此外, 虽然 在以往的研究中对小胶质细胞突起的形态结构也有 分析, 但这些研究在二维平面内测得正常小鼠大脑皮 层中小胶质细胞突起总长度的值低于在三维空间中 的测量结果, 而在二维平面内测得突起末端总数的 值高于在三维空间中的测量结果 ${ }^{[17]}$. 这些差异可能与 这些研究分析方法的不同有关. 小胶质细胞分枝状的 突起在三维空间中的分布十分复杂, 而二维平面内对 其长度的测量结果仅能反映小胶质细胞突起在二维 平面内投影的长度; 此外, 共聚焦显微镜扫描获得的 断层图像在生成二维平面内投影的过程中会产生很 多的突起断端, 这有可能使得在二维平面内测得的突 起末端总数高于真实值. 但是另外一方面, PACT透 明处理会增大脑片面积, 这可能导致经过PACT处理 后小胶质细胞, 突起总长度和所占空间体积的测量结 果大于真实值考虑到细胞间距和细胞体积的增大幅 

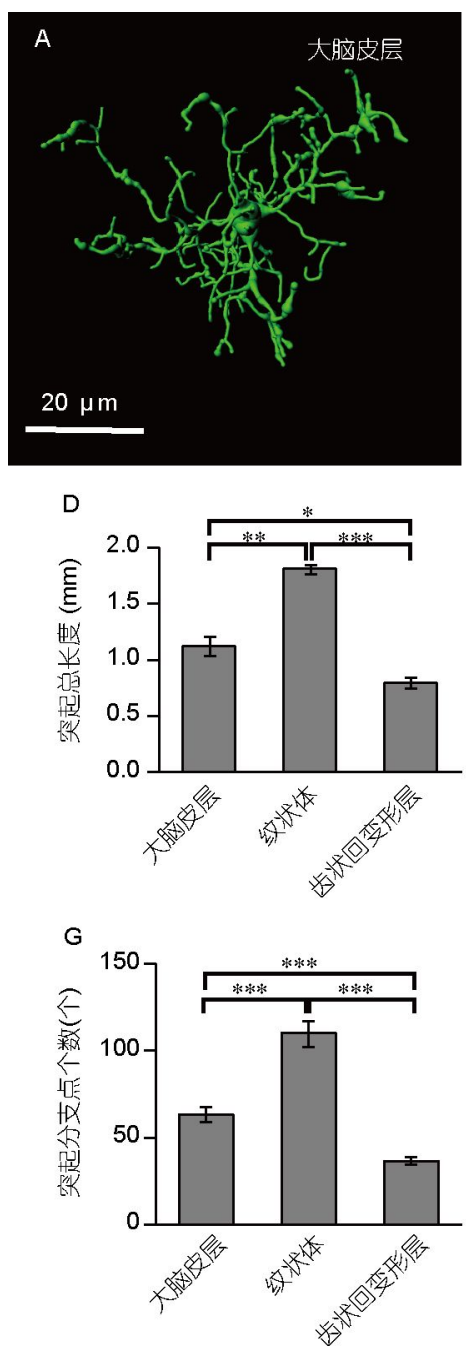
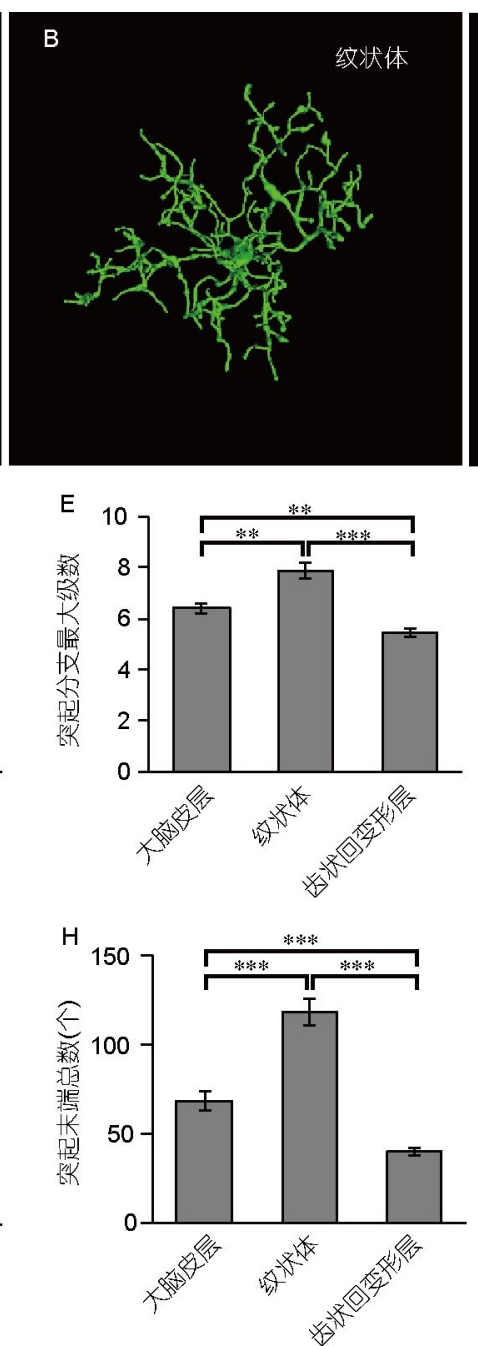
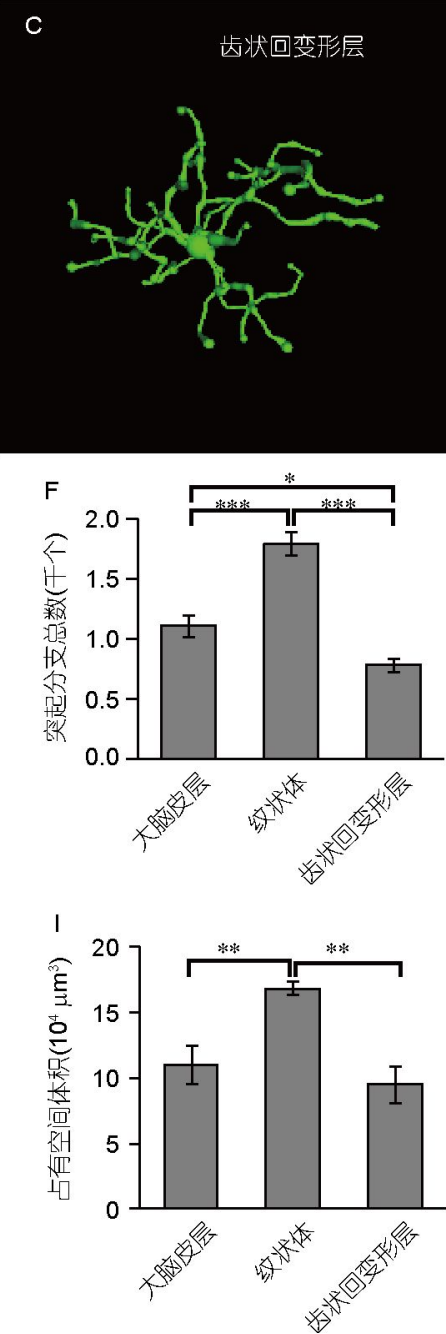

图 3 不同脑区中的小胶质细胞具有不同的结构特征(网络版彩图)

$\mathrm{A} \sim \mathrm{C}$ : 大脑皮层、纹状体和海马齿状回变形层中小胶质细胞的三维重建; D I: 大脑皮层、纹状体和海马齿状回变形层中小胶质细胞突起的总 长度、分支最大级数、分支总数、分支点个数、末端总数和空间占有体积的统计分析 $(n=5$; 双尾 $t$ 检验; *: $P<0.05 ; * *: P<0.01 ; * * *: P<0.001)$

度可能存在不一致的情况，本研究对这些数据没有 进行折算. 虽然PACT透明处理结合共聚焦光学切片 扫描技术分析小胶质细胞的三维形态特征具有一定 的局限性，但与二维分析相比较，三维空间中的多 个量化结果能更加全面地反映小胶质细胞突起的结 构特征.

已有研究表明, 不同脑区中的小胶质细胞具有不 同的形态结构 ${ }^{[11]}$, 本研究在三维水平上的测量结果进 一步显示海马齿状回变形层中小胶质细胞突起的总 长度、分支总数、分支点个数等均显著低于大脑皮 层和纹状体. 以往的研究表明, 突起长度更短, 分支数 更少的小胶质细胞能通过分泌更多的脑源性神经营 养因子(brain derived neurotrophic factor, BDNF)来加强 与学习记忆有关的突触连接 ${ }^{[18]}$. 相对于由更多成熟的 神经元构成的大脑皮层和纹状体 ${ }^{[19,20]}$, 参与学习与记 忆形成的海马齿状回神经元具有更强的可塑性 ${ }^{[21 ~ 23]}$. 海马齿状回中小胶质细胞突起的分支长度更短, 分支 数更少, 这可能与海马齿状回中神经元更高的可塑性 有关.

小胶质细胞分枝状突起的结构复杂且不停地变 化. 在病理学条件下, 小胶质细胞突起的形态变化更 为明显 ${ }^{[24,25]}$, 小胶质细胞结构特征的分析可为病理变 化的评估提供参考. 本研究利用组织透明、光学切片 断层扫描成像和三维重建技术在小鼠大脑中分割出 


\section{参考文献}

1 Vela J M, Dalmau I, González B, et al. Morphology and distribution of microglial cells in the young and adult mouse cerebellum. J Comp Neurol, 1995, 361: 602-616

2 Nimmerjahn A, Kirchhoff F, Helmchen F. Resting microglial cells are highly dynamic surveillants of brain parenchyma in vivo. Science, 2005, 308: $1314-1318$

3 Roth T L, Nayak D, Atanasijevic T, et al. Transcranial amelioration of inflammation and cell death after brain injury. Nature, 2014, 505: 223-228

$4 \mathrm{Hu} \mathrm{X,} \mathrm{Li} \mathrm{P,} \mathrm{Guo} \mathrm{Y,} \mathrm{et} \mathrm{al.} \mathrm{Microglia/macrophage} \mathrm{polarization} \mathrm{dynamics} \mathrm{reveal} \mathrm{novel} \mathrm{mechanism} \mathrm{of} \mathrm{injury} \mathrm{expansion} \mathrm{after} \mathrm{focal} \mathrm{cerebral} \mathrm{ischemia.}$ Stroke, 2012, 43: 3063-3070

5 Grubman A, Kanninen K M, Malm T. Multitasking microglia and Alzheimer's disease: diversity, tools and therapeutic targets. J Mol Neurosci, 2016, 60: 390-404

6 Masuda T, Croom D, Hida H, et al. Capillary blood flow around microglial somata determines dynamics of microglial processes in ischemic conditions. Glia, 2011, 59: 1744-1753

7 Morrison H W, Filosa J A. A quantitative spatiotemporal analysis of microglia morphology during ischemic stroke and reperfusion. J Neuroinflam, 2013, 10: 4

8 Williamson L L, Bilbo S D. Chemokines and the hippocampus: a new perspective on hippocampal plasticity and vulnerability. Brain Behav Immun, 2013, 30: 186-194

9 Cotel M C, Lenartowicz E M, Natesan S, et al. Microglial activation in the rat brain following chronic antipsychotic treatment at clinically relevant doses. Eur Neuropsychopharmacol, 2015, 25: 2098-2107

10 Kettenmann H, Hanisch U K, Noda M, et al. Physiology of microglia. Physiol Rev, 2011, 91: 461-553

11 Lawson L J, Perry V H, Dri P, et al. Heterogeneity in the distribution and morphology of microglia in the normal adult mouse brain. Neuroscience, 1990, 39: 151-170

12 Yang B, Treweek J B, Kulkarni R P, et al. Single-cell phenotyping within transparent intact tissue through whole-body clearing. Cell, 2014, 158: 945-958

13 Jung S, Aliberti J, Graemmel P, et al. Analysis of fractalkine receptor CX3CR1 function by targeted deletion and green fluorescent protein reporter gene insertion. Mol Cell Biol, 2000, 20: 4106-4114

14 Treweek J B, Chan K Y, Flytzanis N C, et al. Whole-body tissue stabilization and selective extractions via tissue-hydrogel hybrids for highresolution intact circuit mapping and phenotyping. Nat Protoc, 2015, 10: 1860-1896

15 Staffend N A, Loftus C M, Meisel R L. Estradiol reduces dendritic spine density in the ventral striatum of female syrian hamsters. Brain Struct Funct, 2011, 215: 187-194

16 Hadeed K, Hascoët S, Amadieu R, et al. 3D transthoracic echocardiography to assess pulmonary valve morphology and annulus size in patients with Tetralogy of Fallot. Archiv Cardiovasc Diss, 2016, 109: 87-95

17 Morrison H W, Filosa J A. Sex differences in astrocyte and microglia responses immediately following middle cerebral artery occlusion in adult mice. Neuroscience, 2016, 339: 85-99

18 Santos-Filho C, de Lima C M, Fôro C A R, et al. Visuospatial learning and memory in the Cebus apella and microglial morphology in the molecular layer of the dentate gyrus and CA1 lacunosum molecular layer. J Chem Neuroanatomy, 2014, 61-62: 176-188

19 Hikosaka O. Basal ganglia - possible role in motor coordination and learning. Curr Opin NeuroBiol, 1991, 1: 638-643

20 Balleine B W, Delgado M R, Hikosaka O. The role of the dorsal striatum in reward and decision-making. J Neurosci, 2007, 27: 8161-8165

21 Kesner R P. An analysis of the dentate gyrus function. Behav Brain Res, 2013, 254: 1-7

22 Vandenbosch R, Clark A, Fong B C, et al. RB regulates the production and the survival of newborn neurons in the embryonic and adult dentate gyrus. Hippocampus, 2016, 26: 1379-1392

23 Baker S, Vieweg P, Gao F, et al. The human dentate gyrus plays a necessary role in discriminating new memories. Curr Biol, 2016, 26: 2629-2634

24 Li T, Pang S, Yu Y, et al. Proliferation of parenchymal microglia is the main source of microgliosis after ischaemic stroke. Brain, 2013, 136: 3578-3588

25 Wang C, Tao S, Fang Y, et al. Infiltrating cells from host brain restore the microglial population in grafted cortical tissue. Sci Rep, 2016, 6: 33080 


\title{
Three-dimensional analysis revealed that microglia have different structural features in different brain regions of mice
}

\author{
CHENG XiaoFeng, JU FuRong \& ZHANG ShengXiang \\ School of Life Sciences, Lanzhou University, Lanzhou 730000, China
}

\begin{abstract}
Microglia are immune cells of the central nervous system, and can constantly monitor the changes in surrounding environment by extending or retracting their ramified processes. To investigate the differences in morphological features of microglia in different brain regions, brain slices of transgenic mice expressing green fluorescent protein (GFP) were prepared and the structure of microglia in the cortex, striatum and polymorph layer of the dentate gyrus (PoDG) were imaged and quantified by combining techniques of tissue clearing, laser scanning confocal microscopy and three-dimensional reconstruction. The individual microglia with complex ramified processes was segmented based on the fact that microglial processes are extended from the cell body and have three-dimensional continuity. The results revealed that the occupied volume of a microglia in the striatum was significantly higher than that in the cortex or PoDG, but there was no significant difference in the occupied volume between the cortex and PoDG. The results of three-dimensional analysis indicated that the total length, the total number, the number of branching points, the total number of endpoints, and the maximum branching level of the microglial processes were significantly different between the cortex, striatum and PoDG. The tissue clearing technique combined with three-dimensional reconstruction can be used to analyze the features of microglial structures from multiple perspectives, and provide a novel approach for further analysis of the relationship between microglial structures and functions and their changes under different pathological conditions.
\end{abstract}

microglia, tissue clearing, three-dimensional reconstruction, mouse

doi: $10.1360 / \mathrm{N} 052016-00343$ 